\title{
Bankacılıkta Kapasite Planlama: Şube Operasyon Faaliyetleri Üzerine Kavramsal Bir İnceleme
}

\author{
Mustafa Tevfik KARTAL*
}

Öz

Türk Bankacılık Sektörü finansal göstergeler açısından büyümesini sürdürmektedir. Buna karşın son zamanlarda sektördeki personel sayısının azaldığı görülmektedir. $\mathrm{Bu}$ gelişmenin temelinde bankaların kapasite planlama faaliyetlerine ağırlık vermeleri ve atıl kapasiteleri tasfiye etmeleri yer almaktadır. Son zamanlarda artan önemi nedeni ile bankacılıkta kapasite planlamaya yönelik bu çalışma hazırlanmıştır. Söz konusu çalışma ile bankacılıkta kapasite planlamaya ilișkin kavramsal çerçevenin ortaya konması amaçlanmıştır. Ek olarak, bankaların kapasite planlama faaliyetlerinde dikkat etmesi gereken hususlar vurgulanmış ve şube operasyon faaliyetleri üzerine bir kapasite planlama örneğine yer verilmiştir. Ayrıca çalışma sonucunda, kapasite planlama faaliyetlerinin sağlıklı șekilde yürütülebilmesi ve bankaların bu faaliyetlerden fayda sağlayabilmeleri için bankalarda menfaat çatışması olmaksızın çalışacak merkezi kapasite planlaması bölümlerinin kurulması önerilmiștir. Türkiye'de bankacılıkta kapasite planlamaya yönelik çalışma bulunmadığından yapılan çalışma bu yönüyle öncü bir çalışma olma özelliği taşımaktadır.

Anahtar Kelimeler: Bankacılık, Faaliyetler, Kapasite Planlama, Türk Bankacılık Sektörü, Türkiye

JEL Sinıflaması: G21, L22

\section{Capacity Planning in Banking: A Conceptual Review upon Branch Operation Activities}

\section{Abstract}

Turkish Banking Sector has been continuing growth in terms of financial indicators. Despite that, it is seen that the number of personnel in the sector has been declining recently. Focus of banks on capacity planning activities and liquidation of idle

Özgün Araştırma Makalesi (Original Research Article)

Geliş/Received: 24.05 .2018

Kabul/Accepted: 26.07 .2018

DOI: http://dx.doi.org/10.17336/igusbd.425789

${ }^{*}$ Dr., Borsa İstanbul A.Ş. Stratejik Planlama ve Yatırımcı İliş̧kileri Direktörlüğü, İstanbul, Türkiye, E-posta: mustafatevfikkartal@gmail.com ORCID ID https://orcid.org/0000-0001-8038-8241 
capacities are at the core of these developments. This work on capacity planning in banking is prepared due to increasing importance in recent times. It is aimed to present the conceptual framework regarding capacity planning in banking with the study. In addition, the issues that banks should pay attention to in capacity planning activities are emphasized and an example of capacity planning on branch operation is given. Also, it is suggested that central capacity planning departments should be set up to work without conflicts of interest in banks so that capacity-planning activities can be carried out in a healthy way and that the banks can benefit from these activities. This paper is pioneer study because of the fact that there is no study about capacity planning in banking sector in Turkey.

Keywords: Banking, Operations, Planning of Capacity, Turkish Banking Sector, Turkey

JEL Classification: G21, L22

\section{Giriş}

Küreselleşmenin hız kazanması ile birlikte dijitalleşme çalışmaları artış göstermektedir. Ülkeler ve sektörler tarafından yakın șekilde takip edilen dijitalleșme çalışmaları teknolojinin yoğun şekilde kullanıldığı sektörlerden biri olan bankacılık sektörü tarafından da yakından takip edilmektedir. Yoğun șekilde teknoloji kullanılması dolayısı ile dijital dönüşümden en fazla faydalanan ve etkilenen sektörlerin başında bankacılık sektörü gelmektedir. Bu yönü ile bankacılık sektörü diğer birçok sektöre kıyasla ön plana çıkmaktadır.

Dijitalleşme bankaların müşterilerine ürün ve hizmet sunma kapasitelerini derinden etkilemektedir. Bu etkinin yanı sıra dijitalleşme, ürün ve hizmetlerin müşterilere sunuluş biçimlerini de değiştirmektedir. Son birkaç yıl öncesine kadar birçok işlemin yapılması için banka şubelerine gitmek gerekirken, günümüzde önemli bankacılık işlemleri olarak sayılabilen hesap açılması ve kredi kullanımı için dahi şubeye gitmeden internet şube veya mobil şube üzerinden işlem yapılabilmektedir. Diğer taraftan banka müşterileri iş ilişkilerini, kendilerine ürün ve hizmet çeşitliliği sağlayan bankalar uzun süreli devam ettirmeyi tercih etmektedirler. Ayrıca müşteri taleplerinin hızlı bir şekilde sonuçlandırılması ve/veya karşılanması müşterilerin bankalarla olan ilişkileri açısından önemli tercih kriterlerinden birini oluşturmaktadır (Kaynak, 1986, s. 58; Khazeh ve Decker, 1992, s. 43). Bu nedenlerle, bankaların müşterilerine ürün ve hizmetleri çeşitli, sürekli ve hızlı sunmaları önem arz taşımaktadır.

Dijitalleşmenin yanı sıra büyük veri de bankacılığı derinden etkilemektedir. Bankalar geçmişe kıyasla günümüzde çok büyük veri yığınları ile uğraşmak durumunda kalmaktadırlar. 10 yıl öncesine kadar bir ticari bankada bir günde bir milyon adet düzeyinde işlem gerçekleşirken günümüzde bu miktar on milyonun üzerine çıkmıştır. Veri hacmi ciddi düzeyde arttığından dolayı bu verileri kullanarak anlamlı sonuçlar çıkarmak ve iş süreçlerinde birer girdi olarak kullanmak gittikçe zorlaşmaktadır. 
Diğer taraftan bankacılıktaki eğilimler dönemsel olarak göstermektedir. Küresel likiditenin azalması ile birlikte uluslararası bankaların daha karlı ülkelere yöneldiği, ülke düzeyinde bakıldığında ise Türkiye'de düşük enflasyon ortamında bankacılık faaliyetlerinin rekabet üzerine kurgulandığı ve dolayısı ile bankaların piyasa payını büyütmeye odaklandığı görülmektedir. Ayrıca bankalar müșteri sınıflandırması, çapraz satışa ağırlık verme, şube ağını iyileştirme, dijitalleşme çalışmaları kapsamında internet bankacılığı ve mobil bankacılık gibi alternatif dağıtım kanallarına odaklanma eğilimleriyle karşı karşıya bulunmaktadır. Bu eğilimlerin her biri bankacılık faaliyetleri üzerinde köklü etkiler oluşturmaktadır.

Küreselleșme, dijitalleșme, büyük veri, sektördeki eğilimler gibi makro hususların yanı sıra ekonomik daralmaların yaşandığı dönemlerde bankacılık sektörü daha zorlu konularla karşı karşıya kalmaktadır. Bankalar bir taraftan mevzuat düzenlemelerine uyum göstermeye çalışırken diğer taraftan maliyetlerini kontrol etmek suretiyle verimlilik sağlamaya, böylece karlılıklarını korumaya çalışmaktadırlar. Karlılığı korumanın gelirleri artırma veya giderleri azaltma yoluyla sağlanabileceği dikkate alındığında zorlaşan ekonomi koşullarında bankalar gelirlerini sınırlı miktarda artırabildikleri için giderlerini azaltmaya odaklanmaktadır. Bankaların finansal tablolarına bakıldığında en önemli maliyet kaleminin personel maliyeti olduğu görülmektedir. Bu nedenle bankalar karlılıklarını korumak ve artırmak için personel maliyetlerini azaltmaya önem vermektedir.

Türk Bankacıllk Sektörü (TBS)'nün şube sayısının gelişimi incelendiğinde ise sektörde 2014 yllsonunda 12.210, 2015 yllsonunda 12.269, 2016 yllsonunda 11.747, 2017 yllsonunda 11.585, 2018 Mart sonunda ise 11.547 şubenin bulunduğu görülmektedir. Buna paralel olarak TBS'nin personel sayısının gelişimi incelendiğinde 2014 yllsonunda 216.880, 2015 yllsonunda 217.504, 2016 yllsonunda 210.910, 2017 yllsonunda 208.280, 2018 Mart sonunda ise 207.952 kişinin sektörde istihdam edildiği görülmektedir (Bankacılık Düzenleme ve Denetleme Kurumu (BDDK), 2014, s. 1; BDDK, 2015, s. 1; BDDK, 2016, s. 1; BDDK, 2017, s. 1; BDDK, 2018, s. 1). Söz konusu rakamlardan görüleceği üzere 2015 yllsonundan itibaren sektördeki şube ve personel sayısı sürekli olarak azalmaktadır. Şube ve personel sayılarındaki bu azalma sektörde maliyetlerin azaltılması için bankaların şube ve personel yapılarını gözden geçirdiklerini ortaya koymaktadır.

Bankalarda bir konu ile ilgili kaynak artırımı veya azaltımı yapılması kapasite planlamanın konusunu oluşturmaktadır. Hangi noktada ne kadar kaynağa ihtiyaç olduğunun ve ihtiyaç fazlası kaynak olup olmadığının belirlenebilmesi, sonrasında ise aksiyon alınabilmesi için öncelikle kapasite planlama çalışması yapılmalıdır. Kapasite planlama çalışmaları ile gereken kaynak miktarının yanı sıra iyileştirme alanları belirlenebilmektedir. Böylece duruma göre kaynak artırmak, kaynak eksiltmek veya kaynak miktarını değiștirmeden iş yapış biçimini değiștirmek suretiyle aksiyon alınması mümkün olmaktadır.

Yukarıdaki açıklamalar dikkate alındığında, bankaların kaynaklarını daha iyi kullanmasının bir zorunluluk olduğu anlaşılmaktadır. Kaynakları etkin kullanmanın önemli yollarından biri bankalarda kapasite planlama yapılmasıdır. Bu makale çalışması bankacılıkta kapasite planlama faaliyetlerine yönelik kavramsal çerçevenin ortaya 
konulması amacıyla hazırlanmıştır. Bilindiği kadarıyla bankacılıkta kapasite planlama konusunda Türkiye'de yapılmış bir çalıșma bulunmamaktadır. Dolayısıyla yapılan bu çalışmanın öncü bir çalışma olma özelliği taşıdığı düşünülmektedir.

Çalışma beş bölümden oluşmaktadır. Giriş bölümünün ardından ikinci bölümde kapasite ve kapasite planlama kavramları ele alınmıștır. Bankacılıkta kapasite planlaması ile ilgili Türkiye'de yapılmış çalışma bulunmadığından kapasiteye ilişkin bazı çalışmalar literatür taraması kapsamında üçüncü bölümde ele alınmıştır. Dördüncü bölümde bankacılıkta kapasite planlamaya ilişkin kavramsal inceleme yapılmıștır. Bu kapsamda şube operasyon faaliyetleri üzerine bir örneğe, bankaların kapasite planlama çalışmalarında dikkat etmesi gereken hususlara ve kapasite planlamanın bankalara faydalarına yer verilmiştir. Son bölümde ise değerlendirme yapılmıştır.

\section{Kapasite ve Kapasite Planlama Kavramları}

Kapasite bir şeyi içine alma, sığdırma sınırı, kapsama gücü, belli bir alana sığabilecek kişi/nesne sayısı, bir işletmenin üretim miktarı, anlama ve kavrama yeteneği olarak tanımlanmaktadır (Türk Dil Kurumu, 2018). Kapasite belirli bir alana sığabilecek en yüksek miktar, görevleri yerine getirebilme becerisi, öğrenmeye dayalı zekâ yetisi, büyüme ve gelişmeye yönelik potansiyel olarak da ifade edilmektedir (Wiktionary, 2018). Kapasitenin farklı kişi ve kurumlar tarafından yapılmıș tanımları da bulunmakta olup bu tanımların bazıları așağıda yer almaktadır:

Kapasite ülkelerin, örgütlerin, grupların veya bireylerin fonksiyonlarını yerine getirecek ve gelişim amaçlarını zaman içinde başarabilecek örgütsel ve teknik yetenekler, ilişkiler ve değerlerdir (Morgan, 1997, s. 2).

Kapasite birey ve grupların sorumluluklarını yerine getirebilme yetisidir (Franks, 1999, s. 52).

Kapasite görevleri etkili, etkin ve sürdürülebilir olarak yerine getirebilme yeteneğidir (Grindle vd., 2007, s. 445).

Kapasite bir sistemin varlığı, uyumu ve işlevlerini yerine getirebilmesini sağlayan davranış, beceri ve ilişkilerin birleşimidir (Brinkerhoff vd., 2010, s. 3).

- $\quad$ Kapasite bir işletmenin üretebileceği mal miktarı, bir geminin taşıyabileceği insan sayısı, bir işçinin çalışabileceği saat, bir makinenin üretebileceği birim miktarıdır (Tekin, 2012, s. 223).

Yukarıda yer verilen çeșitli kapasite tanımları birlikte ele alındığında, kapasite birey veya örgütlerin potansiyel olarak sahip oldukları davranış ve beceri olarak özetlenebilmektedir. Kapasite ile ilgili kritik nokta kapasite geliştirme ve kapasite planlama çalışmalarının yapılmasıyla birlikte kapasite potansiyelinin ortaya çıkarılmasıdır.

Teorik, pratik, gerçek, atıl ve optimum olmak üzere kapasite türleri bulunmaktadır. Teorik kapasite bir işletmede makine ve ekipmanlar üretim için kullanıldığında üretilebilecek maksimum çıktı miktarıdır. Teorik kapasite, kısa dönemde üretilebilecek maksimum çıktı miktarı olarak da tanımlanabilmektedir (Yıldıztekin, 2010, s. 198). Teorik kapasiteden tamir, bakım vb. işletim kesintilerinin çıkarılması ile 
pratik kapasiteye ulaşılır (Yalçınsoy vd., 2014, s. 18). Belirli bir zaman diliminde elde edilen üretim miktarının, yeterli talep olması halinde satılan kısmı gerçek kapasite, satılamayan kısmı ise atıl kapasiteyi ifade etmektedir. Optimum kapasite ise işletmenin birim ortalama maliyetlerini en düşük seviyeye ulaştıran yıllık üretim miktarı olarak tanımlanır (Tekin, 2012, s. 233).

Kapasite planlama faaliyetleri kuruluş seviyesinde başlamakta ve süreklilik gerektirmektedir. Kapasite planlama kararları güncel kapasitenin belirlenmesi, gelecekteki kapasitenin tahmin edilmesi, kapasiteyi etkileyebilecek faktörlerin belirlenmesi, finansal, ekonomik ve teknolojik kapasite alternatiflerinin değerlendirilmesi ve kuruluşun amaçları ile uyumlu kapasitenin seçilmesinden oluşmaktadır (Yalçınsoy vd., 2014, s. 17).

Kapasite planlama çalışmaları ise geniş tabanlı katılım, sürekli öğrenme ve adaptasyon, uzun vadeli yatırım, karmaşık sorunların belirlenebilmesi için farklı seviyelerdeki faaliyetlerin entegrasyonu ilkeleri temelinde gerçekleştirilmektedir. Kapasite planlama ve geliştirme çalışmaları ile birlikte yeni kapasite oluşturma, yenilik ve kapasitenin yaratıcı kullanımı için alan sağlama, mevcut kapasiteyi güçlendirme, mevcut kapasiteyi daha iyi kullanma, eski veya uygun olmayan kapasiteyi tasfiye etme söz konusu olmaktadır. Böylece kapasite açısından mevcut durumundan daha iyi bir duruma geçilebilmektedir.

Kapasite planlama çalışmaları, verilerin toplanması, analiz edilmesi, kapasitenin planlanması ve izlenmesi aşamalarından oluşmaktadır. Bankalarda kapasite planlama çalışmaları kapsamında veri toplama kapsamında kapasite planlaması yapılacak bölüm, şube veya faaliyete ilişkin hedefler, işlem süreleri, işlem adet ve hacimleri, periyodik (dönemsel, günlük, saatlik) iş yükü dağılımı gibi hususlarda veriler toplanmaktadır. Veriler bankanın bütün bölümlerinden ve sistemlerinden alınabilmektedir. Analiz aşamasında toplanan veriler detaylı bir șekilde işlenmektedir. Bu kapsamda bölüm, şube veya faaliyete ilişkin iş yükü, yoğunlaşmalar, normal ve yoğun günler/saatler/sezonlar analiz edilir, aktivite, müșteri ve yokluk analizi yapılır. Planlama aşamasında kapasite çalışması yapılan bölüm, şube veya faaliyet için norm kadrolar belirlenir, norm kadro ile bütçelenen kadrolar uyumlu hale getirilir, kapasite ihtiyacı oluşan hususlar/zamanlar için açı̆̆ın nasıl kapatılacağına ilişkin destek modeli planlanır; ayrıca inceleme sırasında ortaya çıkan gelişim imkânlarına ilişkin proje ve süreç değişiklikleri belirlenerek bunların gerçekleştirilmesine ilişkin planlama yapılır. İzleme aşamasında norm, bütçe ve fiili kadrolar takip edilir, iş yükü genellikle aylık olmaz üzere dönemsel olarak izlenir, riskli addedilen şubeler özellikle ve dikkatlice takip edilir, bankada yürütülmekte olan proje ve süreç değişikliklerinin kapasite açısından takibi yapılır.

\section{Literatür Taraması}

Literatür taramasında bankacılıkta kapasite planlamaya ilişkin Türkiye'de yapılmış herhangi bir çalışmaya rastlanmamıştır. Bununla birlikte kapasiteyi çeşitli açılardan ele alan çalışmalar bulunmaktadır. Literatür taraması kapsamında Türkiye'de yayınlanan çalışmalar arasından seçilenlere Tablo 1'de yer verilmiștir. 


\begin{tabular}{|c|c|c|}
\hline Yazar & Yll & Sonuç \\
\hline Sümer & 2000 & $\begin{array}{l}\text { Gereksiz şubelerin kapatılması, merkez operasyon bölümlerinin } \\
\text { birleştirilmesi sonucu üst yönetim kadrolarının azaltılması ve çeșitli bilişim } \\
\text { teknolojilerinin (BT) birlikte kullanılması gibi etkenler sabit maliyetleri } \\
\text { azaltmaktadır. }\end{array}$ \\
\hline $\begin{array}{l}\text { Bircan ve } \\
\text { Kartal }\end{array}$ & 2004 & $\begin{array}{l}\text { Optimum kapasite kullanımı için doğrusal programlama tekniği } \\
\text { kullanılarak pazar sınırlaması modeli geliştirilmiştir. Böylece darboğazlar } \\
\text { ve atıl kapasiteler belirlenmiştir. }\end{array}$ \\
\hline $\begin{array}{l}\text { Bayraktar } \\
\text { ve Efe }\end{array}$ & 2006 & $\begin{array}{l}\text { Kurumsal kaynak planlaması çözüm alternatiflerini belirlerken kuruluşun } \\
\text { kapasitesi ve büyümesi için yeterli olup olmadığının incelenmesi } \\
\text { gerekmektedir. }\end{array}$ \\
\hline Çevik & 2006 & $\begin{array}{l}\text { Tam sayılı doğrusal programlama kullanılarak işletmede minimum maliyeti } \\
\text { sağlamak için işgücü planını ele alınmıș ve hangi vardiyada hangi } \\
\text { personelden kaç adet çalıştırılması ger ektiği belirlenmiştir. Böylece } \\
\text { personelin yetersiz veya atıl kalması önlenmiştir. }\end{array}$ \\
\hline Küçüksille & 2007 & $\begin{array}{l}\text { İzin dönemlerinde olușan personel ihtiyacının yarı zamanlı çalıșanlarla } \\
\text { kapatılabileceği belirtilmiștir. }\end{array}$ \\
\hline $\begin{array}{l}\text { Keçek ve } \\
\text { Yıldırım }\end{array}$ & 2009 & $\begin{array}{l}\text { Müșteri siparişinin en kısa süre ve maliyetle istenilen kalitede } \\
\text { karşılanabilmesi için dağıtım, üretim ve tedarik kaynaklarının özellikleri ve } \\
\text { kapasiteleri birlikte dikkate alınmalıdır. }\end{array}$ \\
\hline Kerman vd. & 2014 & $\begin{array}{l}\text { Kavram ve yaklaşımların tarihsel olarak sürekli değişime uğradığını } \\
\text { belirlemişlerdir. }\end{array}$ \\
\hline
\end{tabular}

\section{Kaynak: Yazarlar}

Tablo 1: Türkiye'de Yayınlanmış Bazı Çalışmalar

Tablo 1'den görüleceği üzere, kapasite bazı çalıșmalarda sabit maliyetler açısından ele alınmıştır. Sümer (2000), gereksiz şubelerin kapatılması, merkez operasyon bölümlerinin birleștirilmesi sonucu üst yönetim kadrolarının azaltılması ve çeşitli BT kullanılması ile sabit maliyetlerin azaltıldığını belirlemiştir.

Bazı çalışmalarda kapasite personel sayısı açısından ele alınmıştır. Bircan ve Kartal (2004), optimum kapasite kullanımı için doğrusal programlama tekniğini kullanarak pazar sınırlaması modelini geliștirilmiștir. Böylece darboğazları ve atıl kapasiteleri belirlemişlerdir. Çevik (2006), tam sayılı doğrusal programlama yöntemini kullanarak işletmede minimum maliyeti sağlamak için işgücü planını ele almış ve hangi vardiyada hangi personelden kaç adet çalıştırılması gerektiğini belirlemiştir. Böylece personelin yetersiz veya atıl kalması önlenmiştir. Küçüksille (2007) ise izin dönemlerinde oluşan personel ihtiyacının yarı zamanlı çalışanlarla kapatılabileceği sonucuna ulaşmıștır.

Diğer taraftan bazı çalışmalarda kapasite kurumsal kaynak planlaması açısından ele alınmıştır. Bayraktar ve Efe (2006), kurumsal kaynak planlaması çözüm alternatifleri belirlenirken kuruluşun kapasitesinin ve büyüme için yeterli olup olmadığının incelenmesi gerektiği sonucuna ulaşmışlardır.

Yukarıda detaylarına yer verilen Türkiye'deki çalışmaların yanı sıra, kapasiteyi çeşitli açılardan ele alan yurtdışında gerçekleștirilmiş çalışmalar da bulunmaktadır. $\mathrm{Bu}$ çalıșmalar arasından seçilenlere Tablo 2'de yer verilmiștir. 


\begin{tabular}{|c|c|c|c|}
\hline Yazar & Yll & Ülke & Sonuç \\
\hline $\begin{array}{l}\text { Berger ve } \\
\text { Humphrey }\end{array}$ & 1992 & $\mathrm{ABD}$ & $\begin{array}{l}\text { Birleşme ve satın almalarda büyük kapasite seçimi sadece } \\
\text { ölçek ekonomisi yaratmak amaçlı değil stratejik nedenlerle } \\
\text { de yapılmaktadır. }\end{array}$ \\
\hline $\begin{array}{l}\text { Fleischmann } \\
\text { vd. }\end{array}$ & 1997 & Hollanda & $\begin{array}{l}\text { Yeniden üretim faaliyetlerinde daha fazla oranda kapasite } \\
\text { problemleri gözlemlenmektedir. }\end{array}$ \\
\hline Morgan & 1997 & Kanada & $\begin{array}{l}\text { Kapasite geliştirme ile ilgili varsayımlara, göstergelere ve } \\
\text { bazı operasyonel rehberlere yer verilmiştir. Ayrıca kapasite } \\
\text { geliştirmenin özel ilgi ve odaklanma gerektirdiği } \\
\text { belirtilmiştir. }\end{array}$ \\
\hline Morgan & 1998 & Kanada & $\begin{array}{l}\text { Kapasite geliştirme ile ilgili strateji önerilerine yer } \\
\text { verilmiștir. }\end{array}$ \\
\hline Lusthaus vd. & 1999 & Kanada & $\begin{array}{l}\text { Kapasite planlamanın tanımı ile planlanması, izlenmesi ve } \\
\text { değerlendirilmesinde dikkat edilmesi gereken hususlara yer } \\
\text { verilmiş olup kapasite planlamanın henüz gelişme çağında } \\
\text { olduğu belirtilmiştir. }\end{array}$ \\
\hline Bolger & 2000 & Kanada & $\begin{array}{l}\text { Kapasite geliștirmenin nasıl ve niçin yapılması ele alınmış } \\
\text { olup konu ile ilgili önerilere yer verilmiştir. }\end{array}$ \\
\hline Coelli vd. & 2002 & İsveç & $\begin{array}{l}28 \text { uluslararası havayolu şirketi üzerine yapılan ampirik } \\
\text { çalıșma sonucunda şirketlerin potansiyel karlarından } 815 \\
\text { milyon dolar aşağıda kar elde ettiği ve bunun \%70'inin } \\
\text { kullanılmayan kapasiteden kaynaklandığı belirlenmiştir. }\end{array}$ \\
\hline $\begin{array}{l}\text { Sahoo ve } \\
\text { Tone }\end{array}$ & 2009 & Hindistan & $\begin{array}{l}\text { Finansal sektör reformundan sonra oluşan rekabetin etkinlik } \\
\text { artışı sağlayarak atıl kapasiteyi azalttığı sonucuna } \\
\text { ulaşılmıştır. }\end{array}$ \\
\hline Bahl & 2012 & Hindistan & $\begin{array}{l}\text { Elektronik bankacılıkta yeni yatırımların bütçe etkisi, gerekli } \\
\text { yeteneklere sahip personelin kuruluşa çekilme yeteneği ve } \\
\text { dış hizmet sağlayanlara potansiyel bağımlılık gibi hususlar } \\
\text { kapasite planlamada dikkate alınmalıdır. }\end{array}$ \\
\hline
\end{tabular}

Kaynak: Yazarlar

Tablo 2: Yurtdışında Yayınlanmış Bazı Çalışmalar

Tablo 2'den görüleceği üzere, bazı çalışmalar kapasite planlama ve geliştirmeyi kavramsal olarak ele almıştır. Berger ve Humphrey (1992), birleşme ve satın almalarda büyük kapasite seçiminin sadece ölçek ekonomisi yaratmak amaçlı değil aynı zamanda stratejik nedenlerle de yapıldığı sonucuna ulaşmışlardır. Morgan (1997), kapasite geliştirme ile ilgili varsayımlara, göstergelere ve bazı operasyonel rehberlere yer vermiş, bunun yanı sıra kapasite geliştirmenin özel ilgi ve odaklanma gerektirdiğini belirlemiştir. Benzer şekilde Lusthaus vd. (1999), kapasite planlamanın tanımı ile planlanması, izlenmesi ve değerlendirilmesinde dikkat edilmesi gereken hususlara yer vermiş, kapasite planlamanın henüz gelişme çağında olduğunu belirlemişlerdir. Bahl (2012) ise elektronik bankacılıkta yeni yatırımların bütçe etkisi, gerekli yeteneklere sahip personelin kuruluşa çekilme yeteneği ve dış hizmet sağlayanlara potansiyel bağımlılık gibi hususların kapasite planlamada dikkate alınması gerektiği sonucuna ulaşmıştır. Bazı çalışmalarda ampirik araştırma yapılmıştır. Coelli vd. (2002) 28 havayolu şirketi üzerine ampirik çalışma gerçekleştirmişlerdir. Çalışma sonucunda 
şirketlerin potansiyel kar seviyelerinden 815 milyon dolar daha az kar elde ettiği ve bunun \%70'inin kullanılmayan kapasiteden kaynaklandığı belirlenmiştir. Sahoo ve Tone (2009) ise finansal sektör reformu sonrasında rekabetin etkinliğinin artığını ve böylece atıl kapasitenin azaldığı sonucuna ulaşılmışlardır.

Diğer taraftan bazı çalışmalarda kapasite problemleri ele alınmıştır. Fleischmann vd. (1997) yeniden üretim faaliyetlerinde normal üretime kıyasla daha fazla oranda kapasite problemleri gözlemlendiğini ortaya koymuşlardır.

\section{Bankacılık Sektöründe Kapasite Planlama Üzerine Kavramsal İnceleme}

Bankalarda kapasitenin analiz edilmesi ve geliştirilebilmesi için kapasite planlama çalışmaları önem taşımaktadır. Bankalar kapasite planlama çalışmaları ile vizyon ve stratejik hedefleri doğrultusunda atıl kapasite oluşturmadan, yeni darboğazlara yol açmadan ve kapasite genişlemesi yoksa ilave maliyet yaratmadan kaynaklarını etkin bir şekilde planlayarak ideal insan kaynağını belirlemektedirler.

Bu bölümde öncelikle banka şubelerinde kapasite planlama çalışmalarına ilişkin bir örneğe, ardından kapasite planlama çalışmalarının bankalara sağladığı faydalara ve bankaların dikkat etmesi gereken hususlara yer verilmiștir.

\subsection{Bankalarda Kapasite Planlama Çalışmalarına İlişkin Bir Örnek}

Bankalarda bir bölüm, şube veya faaliyete ilişkin kapasitenin hesaplanmasında orada gerçekleştirilen her bir ürün/hizmet/faaliyet ve bunlara ilişkin aktivite adımları ve bunlar için harcanan süreler dikkate alınmalıdır. Kapasite planlamada izlenmesi gereken akışa Şekil 1'de yer verilmiştir.

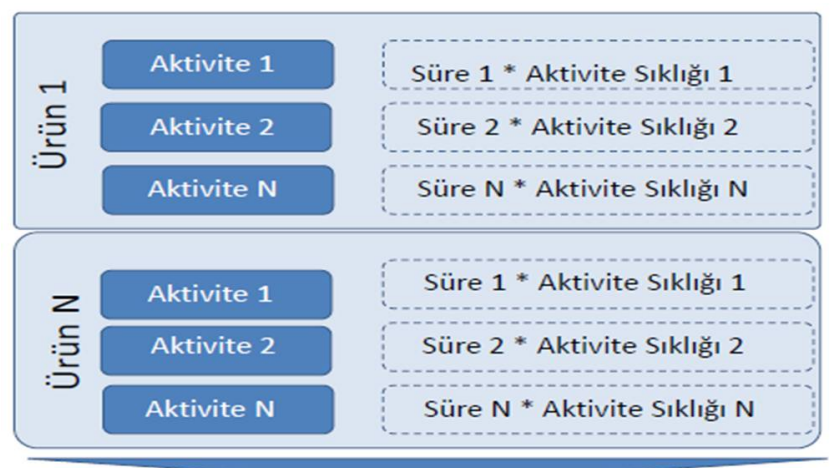

İş Yükü $=\left(\right.$ Süre ${ }^{*}$ Sıklık1+.... + SüreN*SıklıkN $)$

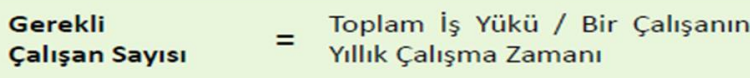

Kaynak: Yazar tarafindan oluşturulmuştur.

Şekil 1: Ürün ve Aktivite Bazlı Hesaplama 
Şekil 1'de yer verilen akış takip edilerek kapasite hesaplaması yapılmaktadır. Şekilde yer verilen akışı somutlaştırmak için bir bankanın ticari şubesinin operasyon kadrosunun kapasite planlaması ele alınacaktır.

Bankanın A Şubesi ticari şubelerden biridir. A Şubesi'nin operasyon kadrosunda mevcutta görev yapan 4 çalıșan bulunmaktadır. Bankanın ticari şubelerinde son zamanlarda iş yoğunluğu, kadro yetersizliği ve müșteri şikâyetlerinde artış görülmesine bağlı olarak kapasite planlama çalışması yapılmasına karar verilmiştir.

Ticari şubelerde operasyon personeli 10 farklı ürün/hizmete ait ișlemler gerçekleștirmektedir. Söz konusu ürün ve hizmetlere ilişkin olarak 1 gün içinde gerçekleștirilen aktivitelere ve ölçülen sürelere Tablo 3'te yer verilmiştir.

\begin{tabular}{|c|c|c|c|c|}
\hline Ürün & Aktivite & $\begin{array}{l}\text { Aktivite } \\
\text { Sıklığı }\end{array}$ & \begin{tabular}{|l|} 
Aktivite \\
Süresi \\
(Dakika) \\
\end{tabular} & $\begin{array}{l}\text { Günlük } \\
\text { Toplam } \\
\text { (Dakika) }\end{array}$ \\
\hline \multirow{3}{*}{ Hesap Açılışı } & Gerekli belgelerin alınması & 10 & 1 & 10 \\
\hline & Sistem kontrollerinin yapılması & 10 & 5 & 50 \\
\hline & $\begin{array}{l}\text { Hesap açlışı için sistem onayının } \\
\text { verilmesi }\end{array}$ & 10 & 1 & 10 \\
\hline \multirow{3}{*}{$\begin{array}{l}\text { İnternet } \\
\text { Bankacılığı } \\
\text { Tanımlanması }\end{array}$} & Gerekli belgelerin alınması & 13 & 2 & 26 \\
\hline & Sistem kontrollerinin yapılması & 13 & 4 & 52 \\
\hline & $\begin{array}{l}\text { Hesap açıllşı için sistem onayının } \\
\text { verilmesi }\end{array}$ & 13 & 1 & 13 \\
\hline \multirow{2}{*}{$\begin{array}{l}\text { Banka Kartı Talep } \\
\text { Edilmesi }\end{array}$} & Eksik bilgilerin tamamlanması & 50 & 2 & 100 \\
\hline & Sistem üzerinden talep yapılması & 50 & 2 & 100 \\
\hline \multirow{2}{*}{$\begin{array}{l}\text { Kredi Kartı Talep } \\
\text { Edilmesi }\end{array}$} & Eksik bilgilerin tamamlanması & 70 & 2 & 140 \\
\hline & Sistem üzerinden talep yapılması & 70 & 2 & 140 \\
\hline \multirow{3}{*}{$\begin{array}{l}\text { Hesap Ekstresi } \\
\text { Verilmesi }\end{array}$} & Talebin alınması & 5 & 1 & 5 \\
\hline & İmza/yetki kontrolü yapılması & 5 & 3 & 15 \\
\hline & \begin{tabular}{|l|} 
Fiziki belge hazırlanması ve \\
müşteriye teslimi
\end{tabular} & 5 & 2 & 10 \\
\hline $\begin{array}{l}\text { Kredi Teklifi } \\
\text { Hazırlanması }\end{array}$ & $\begin{array}{l}\text { Müşteriye ait finansal belgelerin } \\
\text { kontrol edilmesi }\end{array}$ & 10 & 5 & 50 \\
\hline \multirow{3}{*}{$\begin{array}{l}\text { Nakdi Kredi } \\
\text { Kullandırılması }\end{array}$} & Talebin alınması & 40 & 1 & 40 \\
\hline & İmza/yetki/limit kontrolü yapılması & 40 & 8 & 320 \\
\hline & Kredinin kullandırılması & 40 & 2 & 80 \\
\hline \multirow{3}{*}{$\begin{array}{l}\text { Gayrinakdi Kredi } \\
\text { Kullandırılması }\end{array}$} & Talebin alınması & 60 & 1 & 60 \\
\hline & İmza/yetki/limit kontrolü yapılması & 60 & 8 & 480 \\
\hline & Kredinin kullandırılması & 60 & 2 & 120 \\
\hline \multirow{3}{*}{$\begin{array}{l}\text { Çek Karnesi } \\
\text { Verilmesi }\end{array}$} & $\begin{array}{l}\text { İstihbarat kontrollerinin } \\
\text { tamamlanması }\end{array}$ & 15 & 15 & 225 \\
\hline & İmza/yetki/limit kontrolü yapılması & 15 & 8 & 120 \\
\hline & $\begin{array}{l}\text { Çek teslimi için gerekli beyanların ve } \\
\text { teslim tutanağının alınması }\end{array}$ & 15 & 2 & 30 \\
\hline \multirow{2}{*}{$\begin{array}{l}\text { Maaş } \\
\text { Ödemelerinin } \\
\text { Yapılması }\end{array}$} & $\begin{array}{l}\text { Ödeme yapılacak kişilerin listesinin } \\
\text { alınması }\end{array}$ & 1 & 5 & 5 \\
\hline & İmza/yetki/limit kontrolü yapılması & 1 & 7 & 7 \\
\hline
\end{tabular}




\begin{tabular}{|l|l|l|l|l|}
\hline Ürün & Aktivite & $\begin{array}{l}\text { Aktivite } \\
\text { Sıklığı }\end{array}$ & $\begin{array}{l}\text { Aktivite } \\
\text { Süresi } \\
\text { (Dakika) }\end{array}$ & $\begin{array}{l}\text { Günlük } \\
\text { Toplam } \\
\text { (Dakika) }\end{array}$ \\
\hline & $\begin{array}{l}\text { Ödeme yapılacak kişilerin hesap } \\
\text { bilgilerinin kontrol edilmesi }\end{array}$ & 1 & 50 & 50 \\
\cline { 2 - 4 } & $\begin{array}{l}\text { Ödeme işlemlerinin } \\
\text { gerçekleştirilmesi }\end{array}$ & 1 & 22 & 22 \\
\hline 1 Günlük Toplam İş Yükü & & $\mathbf{2 . 2 8 0}$ \\
\hline 1 Yıllık (250 İşgünü) Toplam İş Yükü & $\mathbf{5 7 0 . 0 0 0}$ \\
\hline 1 Çalışanın 1 Yıllık (230 İşgünü) Toplam Çalışma Zamanı & $\mathbf{1 1 0 . 4 0 0}$ \\
\hline Gerekli Çalışan SayıSı & $\mathbf{5 , 1 6}$ \\
\hline
\end{tabular}

Kaynak: Yazar tarafindan oluşturulmuştur.

Tablo 3: Şubede Gerçekleştirilen Ürün ve Hizmetler ile Ölçüm Süreleri

Tablo 3'den görüleceği üzere, A Ticari Şubesi'nde operasyon personeli tarafından 10 ürün/hizmete ait işlemler gerçekleștirilmektedir. Ayrıca her bir ürün/hizmet kapsamında gerçekleștirilen aktiviteler ve bu aktivitelerin ölçülen sürelerine tabloda yer verilmiştir. Kapasite planlama çalışmasının kapsamı operasyon ekibi ile sınırlı olduğu için tabloda sadece operasyon personelleri tarafından gerçekleştirilen aktivitelere yer verilmiştir.

Tablo oluşturulurken 1 yıl 360 gün olarak dikkate alınmış olup 110 gün resmi tatil ve hafta sonu bulunduğu için 250 işgünü üzerinden hesaplama yapılmıștır. Bu durumda A Şubesi'nde operasyon ekibinin toplam 570.000 dakika işi yükü bulunmaktadır. Diğer taraftan A Şubesi'nin operasyon ekibinde 4 çalışan bulunduğu, günlük 8 saat çalıştıkları, çalışanların ortalama yıllık 15 işgünü izin ve 5 gün mazeret izni kullanabilecekleri dikkate alınmıştır.

1 çalıșanın yılda 230 gün ve günlük 8 saat üzerinden yıllık toplam 110.400 dakika çalışabileceği hesaplanmıştır. 10 ürün/hizmete ilişkin şubenin yıllık toplam operasyonel iş yükü 570.000 dakika olduğu dikkate alındığında operasyon ekibi için gerekli kapasite 5,16 (570.000/110.400) olarak hesaplanmaktadır. Operasyon ekibinin 4 kişi olduğu dikkate alındığında A Şubesi'nin ve benzer iş yüküne sahip ticari şubelerin operasyon ekiplerinin kadrosu 4 kişiden 5 kişiye çıkarılmalıdır.

Bankanın ve/veya şubelerin büyüme hedeflerine paralel olarak şubelerin iş yüklerinde iyileștirme çalışmaları, bilgi teknolojileri ve sistem geliștirmeleri gibi çalışmalar nedeniyle bir artış/azalış yaşanması bekleniyorsa, bu hususlar da yukarıda örneği verilen iş yükü hesaplamaları ölçüm sürelerinde dikkate alınmalıdır.

\subsection{Kapasite Planlama Çalışmalarının Bankalara Sağladığı Faydalar ve Bankaların Dikkat Etmesi Gereken Hususlar}

Şube operasyon örneğinden anlaşılacağı üzere, kapasite planlama çalışmaları bankalar açısından çeşitli faydalar içermektedir. Bankaların kapasite planlama çalışmalarından sağladığı faydaların başında her bir bölüm, şube, faaliyet bazında ihtiyaç duyulan insan kaynağının belirlenmesi gelmektedir. Böylece bankalar atıl veya eksik kapasite oluşturmasını engelleyebilmektedir. 
Kapasite planlama çalışmalarının bankalara bir diğer faydası uzmanlaşmış merkezi bir bölüm tarafından kapasite bakış açısı ile faaliyetlerin, süreçlerin, sistemlerin ve projelerin ele alınması, bu sayede gelişim fırsatlarının belirlenebilmesidir. Yapılacak geliştirmeler ile bazı işlemlerde çalışan müdahalesi gereksinimi azaltılabilirken bazı işlemlerde ise çalışan müdahalesine yönelik gereksinim tamamen ortadan kaldırılabilmektedir. Böylece bu işlemler bankanın yazılım sistemleri tarafından otomatik olarak gerçekleştirilebilecek, bu noktada sağlanacak tasarruflar ile artan işlem adetleri ve iş yükü sistemlere yaptırlarak bankanın insan kaynağı kapasitesinde gereksiz artışlar önlenebilecektir.

Diğer taraftan bankaların kapasite planlama çalışmalarından fayda sağlayabilmeleri için bazı hususlara dikkat etmeleri gerekmektedir. Bu hususların başında, sadece ekonomik konjonktürün sıkıntılı olduğu zamanlarda değil iyi olduğu zamanlarda da kapasite planlama çalışmalarına önem verilmesi gelmektedir. Bankalarda genel olarak yapılan hata ise sadece ekonomik daralma dönemlerinde kapasite planlama çalışmalarına ağırlık verilmesi ve kapasite planlamanın bankanın insan kaynağının azaltılmasında bir araç olarak kullanılmasıdır. Bu ise bankalar açısından son derece faydalı olacak kapasite planlamanın faydasız ve hatta zararlı hale gelmesine neden olmaktadır. Bu nedenle kapasite planlama çalışmaları, bankalarda çalışan sayısını azaltmaya yönelik bir faaliyet olarak görülmemeli, aksine işe alım süreçlerine entegre edilerek bankaların genişleme ve büyüme dönemlerinde de aktif rol oynamalıdır. Böylece daha sonraki dönemlere hazırlık yapılmıș olunacaktır.

Kapasite planlama norm kadro hesaplamasına dayanmaktadır. Bu nedenle bankalar norm kadro hesaplarken sistem üzerinden yürütülmeyen faaliyetleri de dikkate almalıdır. Bu şekilde sistemde görülen ve görülmeyen bütün iş yükü üzerinden unvan bazında norm kadro belirlenebilmektedir.

Bankalarda belirli saat, gün ve dönemlerde işlem yoğunluğu söz konusu olabilmektedir. $\mathrm{Bu}$ durumlar için bankaların yokluk yönetimi açısından dikkate alınmalıdır. Böyle durumlarda tam zamanlı insan kaynağı yerine yarı zamanlı, sezonluk veya yoğun gün/zamanlara ilişkin destek kadroları düşünülebilir. Ayrıca görev alanı belirli coğrafi bölgelerle sınırlı olacak şekilde görev yapacak destek elemanları da bir alternatif olarak değerlendirilmelidir. Böylece yoğun zaman diliminde gerekli insan kaynağı talebi ve ihtiyacı karşılanırken yoğun olmayan dönemde atıl kapasite oluşturulmayacaktır.

Kapasite planlama çalışması yapılan şubenin, bölümün, faaliyetin varsa özel durumlarının göz önünde bulundurulması da unutulmamalıdır. Örneğin bir şubeye ilişkin kapasite planlama çalışması yapılıyorsa, bu şubenin yoğunlukla altın, çek-senet alınması-ödenmesi, ipotek işlemleri, avukatlık ödemeleri, dönüşüm projelerinin pilot uygulamalarının yapıldığı bir şube olup olmadığı dikkate alınmalıdır. Ayrıca turizm, tarım, havaalanı, üniversite, gümrük şubesi olup olmadığı, müşterilerin yoğunlukla döviz, kiralık kasa, teminat mektubu işlemi yapıp yapmadığı da göz önünde bulundurularak hangi zaman dilimlerinde yoğunlaşma olup olmadığı belirlenmelidir.

Bankalarda sürekli olarak süreç iyileştirme çalışmaları ve bilgi teknolojileri projelerinin devam ettiği dikkate alındığında, personel üzerinde iş yükü açısından olumlu/olumsuz etkisi olması beklenen projelerin takip edilmesi gerekmektedir. Söz 
konusu çalışmaların etkileri ortaya çıtıkça bu etkiler kapasite planlama çalışmalarına yansıtılarak güncel durum yeniden ortaya konulmalıdır. Ayrıca bankanın ve ilgili bölüm, ekip, faaliyetlerin büyüme beklentileri de kapasite planlama sürecinde dikkate alınmalıdır.

Ayrıca kapasite planlama çalışmalarında öncelikle hedeflerden yola çıkılmalıdır. Hedefleri gerçekleştirmek için ihtiyaç duyulan kapasite tanımlanmalı ve sonrasında bu hedeflere yönelik gerçekleştirilen aktiviteler belirlenmelidir. Belirlenen aktivitelerin süreleri hesaplanmalı, personelden alınan süreler, ölçülen süreler ve bankanın bilgi sistemlerindeki ve veri kaynaklarındaki geçmiş dönem verileri kıyaslanmalıdır.

İş yükleri dönemsel olarak izlenmelidir. Bu noktada önerilen izleme periyodu aylık izleme yapılmasıdır. Böylece izleme görevi üstlenecek kişiler için de aşırı bir iş yükü oluşmayacaktır.

Kapasite planlama çalışmaları gerçekleştirilirken kapasite planlamanın örgütsel boyutu, süreç boyutu, müșteri boyutu ve zaman boyutu ihmal edilmemelidir. Kapasite planlamanın örgütsel boyutu hangi bölümleri, ekipleri, kişileri etkilediği; süreç boyutu hangi süreçleri etkilediği; müşteri boyutu müşterilerin hangi ürün/hizmetleri kullandığı ve zaman boyutu ise kaynak ihtiyacının daimi, sezonluk, günlük, saatlik olması ile ilgilidir. Kapasite planlama çalışmaları gerçekleştirilirken söz konusu dört boyut göz önünde bulundurulmalıdır.

Kapasite planlama çalışmalarının yapılmasında yukarıda belirtilen teknik hususlar göz önünde bulundurulmalıdır. Bu hususların yanı sıra politik ve yasal çerçeve, küresel ve ulusal makroekonomik konjonktür, sektördeki resmi olmayan kural ve uygulamalar, çevresel faktörler, çalışma süresi ile ilgili yasal kısıtlar (normal ve fazla mesai süreleri), personellerin hamilelik durumu ve eğitim planları, yıllık izin ve mazeret izinleri kapasite planlama çalışmalarında dikkate alınmalıdır. Öngörülemeyen durumlar için esneklik payı bırakılması ise kapasite planlama çalışmalarının başarısı açısından kritik öneme sahiptir.

Kapasite planlama açısından önemli hususlardan bir diğeri de bankalarda kapasite planlama çalışmalarının merkezi bir bölüm tarafından yapılmasıdır. Kapasite planlama bölümünün menfaat çatışması olmaksızın çalışmasının sağlanması ile kapasite planlama faaliyetleri sağlıklı bir şekilde sürdürülebilecek, böylece bankalar bu çalışmalardan fayda sağlayabilecektir.

\section{Sonuç}

Bankaların müşterilerine sundukları ürün ve hizmet çeşitliliği günden güne artmaktadır. Bankaların hizmet sunumunda banka içinde birçok bölüm görev almaktadır. Müșterilere hizmetlerin istenilen nitelikte ve en kısa sürelerde sunulması müşterilerin banka ile uzun vadeli iş ilişkilerini sürdürmeleri açısından önem arz taşımaktadır. Ürün ve hizmetlerin müşterilere kısa sürelerde sunulabilmesi banka bölümlerinin gerekli kapasiteye sahip olması ile sağlanabilmektedir.

Kapasite planlama çalışmaları bankaların kaynaklarının etkin ve verimli kullanılması açısından önem taşımaktadır. Kapasite planlaması yapmayan bankalar iç kaynaklarının ne kadar etkin ve verimli kullanıldığını belirleme imkânından mahrum 
kalacaklardır. Bu durumda bazı bölümlerde atıl kapasite oluşurken bazı bölümlerde ise kapasite eksikliği nedeniyle dar boğazlar meydana gelecektir. Bunun yanı sıra kapasite planlama çalışmaları bölümlere birçok konuda temel sorunların ve gelişim alanlarının belirlenmesinde yol gösterici olmaktadır. Dolayısı ile kapasite planlama çalışmaları yapılmadığında veya gereği gibi yerine getirilmediğinde söz konusu sorunların ve gelişim alanlarının belirlenmesi imkânı da kaçırılacaktır.

Kapasite planlama çalışmalarından beklenen faydanın sağlanabilmesi için, bankalar ekonomik konjonktürün sıkıntılı olduğu zamanlardan ziyade iyi olduğu dönemlerde kapasite planlama çalışmalarına ağırlık vermelidir. Böylece bankalar ekonominin iyi olduğu dönemlerde gereksiz yere personel alarak personel maliyetlerini artırmayacak, ekonominin kötü olduğu dönemlerde ise personel çlkararak itibar riskine maruz kalmayacaklardır. Ayrıca kapasite planlama çalışmalarında sistem üzerinden yürütülmeyen faaliyetlerin, yoğun dönemlerin, kapasitesi incelenen bölümlerin, şubelerin özel durumlarının dikkate alınması önem taşımaktadır. Bankalarda yürütülen süreç iyileştirme çalışmalarının ve bilgi teknolojileri projelerinin muhtemel olumlu ve olumsuz etkileri de göz önünde bulundurulmalıdır. İş yüklerinin dönemsel izlenmesi, yasal gerekliliklere uyum ve kapasite planlama çalışmalarının menfaat çatışmalarından uzak merkezi bir bölüm tarafından yürütülmesi ise kapasite planlama çalışmalarının başarısı ve bankalara fayda sağlaması açısından kritik öneme sahiptir.

Endüstri 4.0 olarak ifade edilen yıkıcı inovasyon dönemi, bu dönüşümü yakalayan bankalar için önemli firsatlar sunduğu gibi yakalayamayan bankalar için ciddi tehditler oluşturmaktadır. Söz konusu değişim ve dönüșüm, kapasite planlama çalışmaları açısından tüm bankalarda ve tüm bölümlerde hissedilecektir. Nitekim bankacılıkta kullanılan yoğun teknoloji ve dijitalleşme eğilimi, iş yapış biçimlerini sürekli değiștirmektedir. Değişen iş yapış biçimleri ve ortaya çıkan yeni koşullar, kapasite planlama çalışmalarının tekrar yapılmasını gerekli kılmaktadır.

Kapasite planlama çalışmalarının bankalar için önemi ortada olduğundan, bu faaliyetlerin bankalarda merkezi olarak gerçekleştirilmesinin bir gereklilik olduğu düşünülmektedir. Bunun için tüm bankalarda kapasite planlama faaliyetlerini yerine getirmek üzere kapasite planlama bölümlerinin kurulması önerilmektir. Ayrıca bankaların tüm bölümleri için kapasite planlama çalışmaları yapılması faydalı olacağından, kapasite planlama bölümlerinin diğer bölümlerin etkisinde kalmadan çalışabilmesi sağlanmalıdır.

Son olarak, Türk Bankacılık Sektöründe faaliyet gösteren bankaların kapasite planlama ile ilgili tecrübelerini kuruluş birlikleri üzerinden paylaşmaları halinde literatür derinleștirilebilecek ve bankaların kapasite planlama çalışmalarına yönelik detaylı analizler ve karşılaştırmalar içeren çalışmalar yapılabilecektir.

\section{KAYNAKÇA}

BDDK. (2014). Türk bankacılık sektörü temel göstergeleri Aralık 2014. https://www.bddk.org.tr/WebSitesi/turkce/Raporlar/TBSGG/13810tbs temel gosterge ler.pdf, 21.05.2018. 
BDDK. (2015). Türk bankacılık sektörü temel göstergeleri Aralık 2015.

https://www.bddk.org.tr/WebSitesi/turkce/Raporlar/TBSGG/15175tbs temel gosterge ler aralik 2015.pdf, 21.05.2018.

BDDK. (2016). Türk bankacılık sektörü temel göstergeleri Aralık 2016.

https://www.bddk.org.tr/WebSitesi/turkce/Raporlar/TBSGG/15785tbs temel gosterge ler raporu aralik 2016.pdf, 21 Mayıs 2018.

BDDK. (2017). Türk bankacılık sektörü temel göstergeleri Aralık 2017.

https://www.bddk.org.tr/WebSitesi/turkce/Raporlar/TBSGG/16668tbs temel gosterge ler_raporu aralik 2017.pdf, 21.05.2018.

BDDK. (2018). Türk bankacılık sektörü temel göstergeleri Mart 2018.

https://www.bddk.org.tr/WebSitesi/turkce/Raporlar/TBSGG/16951tbs temel gosterge ler mart 2018.pdf, 21.05.2018.

BAHL, S. (2012). E-banking: Challenges \& policy implications. International Journal of Computing \& Business Research, Conference I-Society, ss. 1-12.

BAYRAKTAR, E. \& EFE, M. (2006). Kurumsal kaynak planlaması (ERP) ve yazılım seçim süreci. Selçuk Üniversitesi Sosyal Bilimler Enstitüsü Dergisi, (15), 689-709.

BERGER, Allen N. \& HUMPHREY, David B. (1992). Megamergers in banking and the use of cost efficiency as an antitrust defense. Antitrust Bulletin, 37(3), 541-600.

BIRCAN, H. \& KARTAL, Z. (2004). Doğrusal programlama tekniği ile kapasite planlaması yaklaşımı ve çimento işletmesinde bir uygulaması. CÜ Íktisadi ve İdari Bilimler Dergisi, 5(1), 131-149.

BOLGER, J. (2000). Capacity development: Why, what and how?. Canadian International Development Agency, Capacity Development Occasional Series, 1(1), 1-8.

BRINKERHOFF, D. W. \& MORGAN, P. J. (2010). Capacity and capacity development: coping with complexity. Public Administration and Development, 30(1), 2 10 .

COELLI, T., GRIFELL-TATJE, E. \& PERELMAN, S. (2002). Capacity utilization and profitability: A decomposition of short-run profit efficiency. International Journal of Production Economics, 79(3), 261-278.

ÇEVIK, O. (2006). Tam sayılı doğrusal programlama ile işgücü planlaması ve bir uygulama. Afyon Kocatepe Üniversitesi İIBF Dergisi, 8(1), 157-171.

FLEISCHMANN, M., BLOEMHOF-RUWAARD, J. M., DEKKER, R., Van Der LAAN, E., Van NUNEN, J. A. E. E. \& Van WASSENHOVE, L. N. (1997). Quantitative models for reverse logistics: A review", European Journal of Operational Research, 103(1), 1-17.

FRANKS, T. (1999). Capacity building and institutional development: Reflections on water. Public Administration and Development, 19(1), 51-61.

GRINDLE, M. S. \& HILDERBRAND, M. E. (2007). Building sustainable capacity in the public sector: What can be done?. Public Administration and Development, 15(5), 441-463.

KAYNAK, E. (1986). How to measure your banks personality: Some insights from Canada", International Journal of Bank Marketing, 16 (5), 54-68.

KEÇEK, G., YILDIRIM, E. (2009). Kurumsal kaynak planlaması (ERP) ve işletme açısından önemi. Elektronik Sosyal Bilimler Dergisi, 8(29), 240-258. 
KHAZEH, K. \& DECKER, W. H. (1992). How customer choose banks?, The Journal of Retail Banking, 14 (4), 41-44.

KERMAN, U., AKTEL, M., ALTAN, Y., ALTUNOK, M. \& TEK, H. (2014). Dünya Bankası ve Birleşmiş Milletler kalkınma programının kapasite geliștirme yaklaşımı, Gazi Üniversitesi İktisadi ve İdari Bilimler Fakültesi Dergisi, 16(1), 145-176.

KÜÇÜKSILLLE, E. U. (2007). İş yoğunluğu tahmini ve işgücü planlama: Süpermarket uygulaması. (Yayınlanmamıș Doktora Tezi). Süleyman Demirel Üniversitesi Sosyal Bilimler Enstitüsü, Isparta.

LUSTHAUS, C., ADRIEN, M. H. \& PERSTINGER, M. (1999). Capacity development: Definitions, issues and implications for planning, monitoring and evaluation. Universalia Occasional Paper, No: 35, 1-21.

MORGAN, P. (1997). The design and use of capacity development indicators, political and social policies division. Policy Branch, Hull: Canadian International Development Agency, 1997.

MORGAN, P. (1997). Capacity and capacity development-Some strategies, political and social policies division. Policy Branch, Hull: Canadian International Development Agency, 1998.

SAHOO, B. K. \& TONE, K. (2009). Decomposing capacity utilization in data envelopment analysis: An application to banks in India. European Journal of Operational Research, 195(2), 575-594.

SÜMER, S. (2000). Banka birleşmeleri, Active, Şubat-Mart, (5).

TEKIN, M. (2012). Üretim yönetimi. 8. Baskı, Konya.

Türk Dil Kurumu. (2018). Kapasite. http://www.tdk.gov.tr, 21.05.2018.

Wiktionary. (2018). Capacity. https://tr.wiktionary.org, 21.05.2018.

YALÇINSOY, A., ZINCIRKIRAN, M. \& TIFTIK, H. (2014). Approach of capacity planning through linear programming technique: A practice in textile enterprise. International Journal of Innovative Research in Management, 3(3), 16-29.

YILDIZTEKİN, İ. (2010). Așırı kapasite kontrolü ve maliyet analizi. Atatürk Üniversitesi İktisadi ve İdari Bilimler Dergisi, 24(3), 197-228.

\section{Summary}

As a result of the increasing globalization and digitization process, way of doing business in banks has been changing so rapidly. In this context, cost management has been gaining much more importance it has ever been as well as capacity usage. So, banks have been reviewing their personal and branches and the figures show that they are decreasing. From this point of view, it can be seen that banks have been staffing up and closing branches in order for that they want to take under control costs. Also, this condition shows us that banks have not been deploying capacity planning on time and correctly. If they did so, they have not been staffing up and not been closing branches so much.

In this study, capacity planning is examined conceptually and it is intended to provide a conceptual framework for capacity planning activities in banking. In this context, 
firstly capacity planning is explained in terms of conceptually. Secondly, an example regarding operational activities in bank branch is examined. And thirdly, benefits of capacity planning are determined and the important points that banks should have to pay attention are defined. As a result of the analysis, it is stated that all banks should establish a central capacity planning department so that they could benefit from capacity planning activities. Also the independence workplace in which capacity planning departments work in banks and the time at which capacity planning activities are hold, are important in order to be able to provide benefits of banks from capacity planning activities. 